\title{
Meta
}

Journal des traducteurs

Translators' Journal

\section{Hérelle, GeORges (2005) : Petit mémoire d'un traducteur. Bruxelles : Les Éditions du Hazard, 126 p.}

\section{Hugo Vandal-Sirois}

Volume 55, numéro 3, septembre 2010

URI : https://id.erudit.org/iderudit/045081ar

DOI : https://doi.org/10.7202/045081ar

Aller au sommaire du numéro

Éditeur(s)

Les Presses de l'Université de Montréal

ISSN

0026-0452 (imprimé)

1492-1421 (numérique)

Découvrir la revue

Citer ce compte rendu

Vandal-Sirois, H. (2010). Compte rendu de [HÉrelle, Georges (2005) : Petit mémoire d'un traducteur. Bruxelles : Les Éditions du Hazard, 126 p.] Meta,

55(3), 604-606. https://doi.org/10.7202/045081ar

Ce document est protégé par la loi sur le droit d'auteur. L'utilisation des services d'Érudit (y compris la reproduction) est assujettie à sa politique d'utilisation que vous pouvez consulter en ligne.

https://apropos.erudit.org/fr/usagers/politique-dutilisation/
Cet article est diffusé et préservé par Érudit.

Érudit est un consortium interuniversitaire sans but lucratif composé de l'Université de Montréal, l'Université Laval et l'Université du Québec à Montréal. Il a pour mission la promotion et la valorisation de la recherche. https://www.erudit.org/fr/ 
Hérelle, Georges (2005): Petit mémoire d'un traducteur. Bruxelles: Les Éditions du Hazard, $126 \mathrm{p}$.

Lorsque le traducteur littéraire français Georges Hérelle (1848-1935) a fait don à la Bibliothèque de Troyes de tous les documents de travail qu'il a accumulés en une trentaine d'années de métier et de la correspondance qu' il a entretenue avec «ses» auteurs principaux, il ne devait certainement pas s'imaginer qu'un petit livre en serait tiré quelque 80 années plus tard. Pourtant, parmi toutes ces notes se trouvait le manuscrit du Petit mémoire d'un traducteur, un texte à mi-chemin entre l'essai et l'autobiographie, très accessible et intéressant pour ceux qui s'intéressent à la traduction et à son histoire. Jean-Marie Van der Meerschen, fondateur des Éditions du Hazard, maison d'édition de l'Institut supérieur de traducteurs et interprètes de Bruxelles consacrée à la traductologie et à la linguistique, y a vu une belle occasion de présenter la traduction française au tournant du $\mathrm{xx}^{\mathrm{e}}$ siècle. Par ailleurs, la publication de ce Petit mémoire d'un traducteur est également un hommage à Georges Hérelle lui-même, professeur et historien passionné de traduction, qui a fait découvrir aux lecteurs francophones de grands auteurs italiens et espagnols tels que Gabriele D'Annunzio, Grazia Deledda, Matilde Serao et Vicente Blasco Ibáñez.

C’est avec bonhomie que Hérelle révèle sa vie de traducteur, les défis linguistiques et culturels auxquels il a été confronté ainsi que différents points de vue sur la théorie et la pratique de la traduction. Dans la préface, Van der Meerschen s'empresse toutefois de préciser que ces écrits remontent à la fin de la Première Guerre mondiale et que les propos de Hérelle pourront sembler désuets aux yeux des traductologues d'aujourd'hui. Notons tout de même que le traducteur français aborde, sans les nommer bien sûr, des notions toujours d'actualité en traductologie comme l'équivalence, les shifts ou encore le dilemme traduction ethnocentrique - traduction exotisante.

Dans l'introduction, Hérelle explique comment il est devenu traducteur par hasard. Ce récit agréable à lire, ponctué d'anecdotes et toujours teinté d'une couleur très personnelle, démontre un talent de conteur étonnant chez l'auteur. D'emblée, Hérelle donne le ton en s'attaquant aux traducteurs tâcherons qui multiplient les travaux vite faits pour de simples raisons pécuniaires. Le traducteur, avance-t-il, doit plutôt respecter sa conscience littéraire en ne choisissant que de grandes œuvres dignes d'être présentées à l'étranger, quitte à le faire gratuitement. Cette dernière proposition peut par ailleurs faire sourire, lorsqu'on sait que Hérelle était choyé par son éditeur et bénéficiait de conditions exceptionnelles (Wilfert-Portal, 2002).
Dans le premier chapitre, Hérelle aborde l'éthique que tous les traducteurs littéraires devraient démontrer lorsqu'il s'agit de choisir une œuvre à traduire. Il répète qu'il est inutile de traduire des ouvres médiocres, même s'il s'agit de succès populaires. À son sens, les œuvres dépourvues d'originalité ne méritent pas d'être traduites, et c'est pourquoi il ne s'est intéressé qu'à des récits fortement ancrés dans la culture de leur pays d'origine (contrairement, par exemple, à des romans italiens ou espagnols qui s'inspirent de la littérature française de l'époque). Bien entendu, ce traducteur quelque peu utopique, qui ne traduit que pour l'amour de l'art et dont la nature de la tâche ne dépend que du bon goût et des coups de cœur personnels, appartient à une époque sans agent littéraire, où il suffisait d'approcher tout bonnement l'auteur pour obtenir sa bénédiction. C'est également dès ce premier chapitre que Hérelle formule deux opinions assez tranchées sur la traduction, qui résument bien les différentes réflexions présentes tout au long de son Petit mémoire d'un traducteur: "Pour ce qui me concerne, j'ai toujours été convaincu que ce ne sont pas les théories qui engendrent les chefs-d'œuvre, et qu'au contraire, ce sont les chefs-d'œuvre qui fournissent les modèles aux théoriciens. », et « [...] sa tâche [du traducteur ] est non de créer, mais de faire connaître les créations d'autrui» (p. 27). Hérelle insistera d'ailleurs sur l'importance de conserver des éléments exotiques.

Les relations entre l'auteur et le traducteur sont abordées dans le deuxième chapitre. Hérelle y décrit son premier contact avec les auteurs dignes d'être traduits, et le rôle que ces derniers jouent durant le processus de traduction. Il faut dire que Hérelle entretenait de longs échanges avec eux et qu'il demandait continuellement leur approbation. Il lit attentivement les corrections que les auteurs font à son travail, convaincu que même si leurs suggestions ne sont pas satisfaisantes, elles indiquent un quelconque manque dans la première version de la traduction. Cependant, il rejette toutes les modifications faites par l'auteur lorsqu'il les juge inférieures à son propre travail (il mentionne entre autres toutes les corrections suggérées par D’Annunzio, écrites dans un français approximatif). Après tout, pour Hérelle, il est clair que si l'auteur exerce une souveraineté sur le fond de l'œuvre, le traducteur est responsable de la forme. Il n'hésite donc pas à corriger les faiblesses de l'œuvre originale (répétitions, impropriétés, désordre dans les idées), et se justifie en ajoutant qu'aucun auteur ne lui a reproché ces initiatives.

Le troisième chapitre, le cœur de l'ouvrage, porte sur le Labeur du traducteur. Hérelle explique comment il s'y prend pour traduire une ouvre et pour trouver des solutions aux différents problèmes 
qui peuvent survenir, en puisant de nombreux exemples dans ses archives personnelles. Il entame le chapitre par des réflexions sur la traduction et ses enjeux. Il se distancie d'emblée de la traduction littérale, estimant qu'une traduction libre peut être bien plus fidèle que du mot à mot. Par ailleurs, il affirme, malgré son penchant pour l'approche sourcière, qu'une traduction doit bien sûr recréer l'effet du texte original en puisant dans la richesse de la langue cible. Le traducteur ne doit pas trop conserver les particularités du texte et de la langue d'origine, ce que Hérelle appelle des traductions rédigées en petit nègre. Il tempère ainsi ses propos précédents en parlant désormais d'équilibre. Dans la seconde partie du chapitre, Hérelle dresse et commente une liste de cinq points problématiques pour les traducteurs. D'abord les titres, difficiles, car ils ne sont que quelques mots chargés de sens et souvent dotés d'une grande musicalité. La question des noms propres est ensuite abordée. Hérelle mentionne que bien qu'il lui arrive de franciser certains noms, il conseille plutôt de conserver les noms originaux pour donner au lecteur une sensation d'exotisme. Il propose une solution semblable au point suivant, celui des termes techniques et étrangers. Hérelle suggère de garder ces mots tels quels, quitte à ajouter des explications dans le texte ou même un lexique à la fin de l'œuvre. Le quatrième point listé concerne les dialectes. Il est fortement recommandé de les traduire comme s'il s'agissait d'un passage normal, plutôt que d'opter pour un quelconque argot français, ce qui serait absurde. Finalement, le dernier point porte sur la fidélité. Hérelle y explique comment il évite les contre-sens, et affirme qu'il refuse catégoriquement d'utiliser une formulation vague pour ne pas avoir à choisir entre deux interprétations divergentes. Il attaque au passage les disciples des Belles Infidèles, déclarant que l'on «dénature plus le style d'un auteur en le forçant qu'en l'affaiblissant» (p. 75). Bref, bien que l'argumentation de Hérelle semble parfois rudimentaire et catégorique, les énoncés sont souvent accompagnés d'exemples aussi éloquents que pertinents. On reconnaît par ailleurs dans ce chapitre des idées développées plusieurs décennies plus tard par Vinay et Dalbernet (1958) dans leur Stylistique comparée du français et de l'anglais, comme l'emprunt ou encore l'équivalence.

Moins intéressants pour le traducteur d'aujourd'hui mais riches en informations pour les historiens, les quatrième et cinquième chapitres abordent respectivement la publication des traductions et le succès de celles-ci. Hérelle y dresse un portrait des conditions de travail des traducteurs littéraires de l'époque et du genre de relation qu'ils entretenaient avec les maisons d'édition. Il affirme notamment avoir la même loyauté envers les maisons d'édition qu'envers les auteurs. Le cinquième chapitre com- mence ensuite par une liste des sept étapes de la correction des traductions. Ce passage, intéressant dans la mesure où il illustre l'évolution de son travail, aurait toutefois trouvé une meilleure place dans le troisième chapitre qui, après tout, traite du travail du traducteur. Le lecteur trouve finalement une série d'extraits de lettres et de critiques très élogieuses de son travail. On pourrait évidemment se questionner sur l'utilité de ce dernier chapitre, d'autant plus que Hérelle a déjà "subtilement» mentionné à quel point son œuvre a été appréciée et ce, à maintes reprises. Toujours est-il qu'il nous confie sur un ton grave qu'avec ses fonctions universitaires et son travail de traducteur, son horaire surchargé lui a souvent causé de «violentes coliques hépatiques» (p. 106). Traducteurs bourreaux de travail, vous voilà avertis!

L'ouvrage se termine par une annexe composée de trois éléments, dont le plus intéressant présente les trois devoirs du traducteur: envers luimême (il doit choisir de traduire des œuvres pour les bonnes raisons), envers l'auteur (en demeurant fidèle) et envers les éditeurs (en ne suggérant que des textes exceptionnels). Hérelle présente ensuite de brèves réflexions sur les similarités entre le métier de traducteur et celui de sculpteur, avant de revenir sur la traduction des poèmes, la musicalité des vers et l'équivalence dans la traduction de la poésie. Finalement, un index des personnes et entreprises mentionnées par Hérelle dans son mémoire s'avérera peut-être utile aux lecteurs qui s'intéressent davantage à l'histoire de la traduction.

Bref, bien que ce Petit mémoire d'un traducteur n'apprenne pas grand-chose aux traducteurs et aux terminologues du point de vue technique ou théorique, il n'en demeure pas moins un ouvrage agréable et parfois étonnant. L'écriture de Hérelle est habile et ses réflexions, vivement imagées. Encore une fois, les situations évoquées par Hérelle sont souvent difficilement imaginables aujourd'hui, mais là n'est pas l'intérêt de l'œuvre. Malgré quelques contradictions et certains passages quelque peu déroutants, comme le fait qu'il semble tenir pour acquis que l'auteur sera continuellement à la disposition du traducteur, le Petit mémoire d'un traducteur méritait effectivement d'être publié, ne fut-ce que pour en savoir plus sur le quotidien des traducteurs des $\mathrm{XIX}^{\mathrm{e}}$ et $\mathrm{XX}^{\mathrm{e}}$ siècles. Reste à savoir si Hérelle lui-même estimerait qu'il s'agit d'une œuvre digne d'être traduite!

Hugo VANDAL-Sirois

Université de Montréal, Montréal, Canada

\section{RÉFÉRENCES}

Vinay, Jean-Paul et DARbelnet, Jean (1958): Stylistique comparée du français et de l'anglais. Montréal: Beauchemin. 
Wilfert-Portal, Blaise (2002): Cosmopolis et l'homme invisible, Actes de la recherche en sciences sociales 2(144):33-46.

Mattila, Heikri (2006): Comparative Legal Linguistics. Aldershot: Ashgate, 347 p.

Legal linguistics in its various national guises: linguistique juridique, jurilinguistique, Rechtslinguistik, ${ }^{1}$ etc. has been the subject of very few monographs. This deficieny was redressed in 1990 with the publication of Gérard Cornu's Linguistique Juridique in which the author admitted that la linguistique juridique had yet to find its place in the list of established branches of knowledge: "ne figure pas à la nomenclature des branches du savoir" (Cornu 1990: 13). Heikki Mattila's Comparative Legal Linguistics ${ }^{2}$ is a very welcome addition to this tradition in what is a discipline in statu nascendi. It examines the "development, characteristics and usage of" the major legal languages (p. 11) while also drawing on examples from minor languages including Finnish, Swedish, and Danish. The synthesis found in Cornu's work is also evident here. Not only the legal lexicon but also legal phraseology and style are examined. The author has outlined elsewhere the desiderata of studies in legal linguistics:

[t]he vocabularies of modern legal languages must be juxtaposed in their entirety. Simultaneously, it is important to compare the other characteristics of legal languages (their styles, etc.). All these comparisons must have legal depth: often differences which exist today can only be understood on the basis of earlier developments (Mattila 2006: 31).

These requirements are, for the most part, successfully met in the current work.

In the general introduction, the discipline is situated within legal science and defined in terms of its relationship with cognate areas such as comparative law, legal semiotics and legal informatics. The rest of the book is divided into three main parts: legal language as a Language for specific purposes (LSP), the major legal languages and a concluding section on lexical comprehension and research needs. In the first part, the author examines the characteristics of legal language as an LSP and illustrates how these are in part determined by the functions law has to perform. These characteristics include formalism, precision, archaism, abstraction, remoteness, noun-sickness (the density of nouns), etc. The originality of legal syntax is also illustrated by means of an example. The operative part of some Danish judgments still includes the following sentence: sagsøgte bør for sagsøgers påstand fri at vore (the defendant is acquitted of the plaintiff's claim). According to normal word order, the end of this sentence would be bør voere fri (p. 84). One is reminded that all legal languages share specific characteristics. This acknowledgment of the particularity of legal syntax is at variance with the stance of Cornu (1990: 35) who argues that the language of the law has no specific syntax. In his discussion of legislative discourse, he does, however, point to some syntactical peculiarities such as ellision, ellipsis, etc. ${ }^{3}$ The dependence of legal French on the syntactic rules of ordinary French is also stressed by Sourioux and Lerat (1995: 328). However, one need only peruse any legal judgment of a French court to be convinced of the originality of legal syntax: the use of the preposition en where one expects dans or à in phrases like en la Cour, en la forme, en ses réquisitions or the use of près (without de) instead of auprès de in phrases such as près le Tribunal, près la Cour d'appel make for a readily identifiable legal syntax (Raymondis and Le Guern 1976: 17-27). Peculiarities of syntax also abound in English legal discourse (Charrow and Charrow 1979: 1306). Klinck (1992: 254) points out that syntactic choices are relevant to the way legal discourse characteristically creates meaning. The distinctiveness of legal syntax, then, while perhaps not complete is surely more than a question of variety in the "frequency and distribution of the use of specific aspects of grammar" or "some minor differences in grammatical construction" (Gibbons 2003: 55).

The major legal languages, Latin, French, German, and English, form the basis of the second part of the book. Examples from legal Italian, legal Spanish and legal Russian also enrich other parts of the analysis. The most original part of this section is the treatment of legal Latin. After tracing the history of legal Latin (p. 126), the author looks at the status of Latin in modern legal languages and examines the value of Latin in international communication between lawyers (p. 136). This shared terminology would appear, at first glance, to facilitate the international lawyer and the translator's task. Indeed, the case for the adoption of Latin as a lingua franca in law has been made by some commentators who note that translation between systems that are based on Roman law is less problematic than those which do not go back to a common origin. Grossfeld has pointed out that the use of Latin as a universal language in the Middle Ages and right up until the modern era resulted in a situation where "law frees itself from the local environment and the abstract idea (universality) of law appears as the universal reality severed from environment and language" (Grossfeld 2005: 40). The author, however, urges caution and points out that the translator grappling with Latin terminology soon 